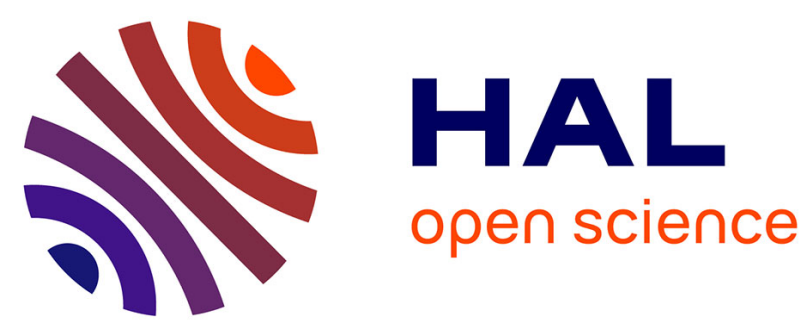

\title{
Thinning has a positive effect on growth dynamics and growth-climate relationships in Aleppo pine (Pinus halepensis ) trees of different crown classes
}

Jorge Olivar, Stella Bogino, Cyrille Rathgeber, Vivien Bonnesoeur, Felipe Bravo

\section{To cite this version:}

Jorge Olivar, Stella Bogino, Cyrille Rathgeber, Vivien Bonnesoeur, Felipe Bravo. Thinning has a positive effect on growth dynamics and growth-climate relationships in Aleppo pine (Pinus halepensis ) trees of different crown classes. Annals of Forest Science, 2014, 71 (3), pp.395-404. 10.1007/s13595013-0348-y . hal-01101539

\section{HAL Id: hal-01101539 \\ https://hal.science/hal-01101539}

Submitted on 8 Jan 2015

HAL is a multi-disciplinary open access archive for the deposit and dissemination of scientific research documents, whether they are published or not. The documents may come from teaching and research institutions in France or abroad, or from public or private research centers.
L'archive ouverte pluridisciplinaire HAL, est destinée au dépôt et à la diffusion de documents scientifiques de niveau recherche, publiés ou non, émanant des établissements d'enseignement et de recherche français ou étrangers, des laboratoires publics ou privés. 


\title{
Thinning has a positive effect on growth dynamics and growth-climate relationships in Aleppo pine (Pinus halepensis) trees of different crown classes
}

\author{
Jorge Olivar • Stella Bogino • Cyrille Rathgeber • \\ Vivien Bonnesoeur $\cdot$ Felipe Bravo
}

Received: 2 June 2013 / Accepted: 15 November 2013 / Published online: 13 December 2013

(C) INRA and Springer-Verlag France 2013

\begin{abstract}
- Context Modification of stand density by thinning may buffer the response of tree growth and vigor to changes in climate by enhancing soil water availability.

- Aims We tested the impact of thinning intensity on cambial growth of Aleppo pine (Pinus halepensis L.) under semi-arid, Mediterranean conditions.

- Methods A multiple thinning experiment was established on an Aleppo pine plantation in Spain. We analysed the stem growth dynamics of two different crown classes under four different thinning intensities $(15 \%, 30 \%$, and $45 \%$ removal
\end{abstract}

\section{Handling Editor: Gilbert Aussenac}

Contribution of the co-authors Jorge OLIVAR: writting the paper, data analysis, field measurements.

Stella BOGINO: supervising the work

Cyrille RATHGEBER: supervising the work

Vivien BONNESOEUR: data analysis.

Felipe BRAVO: supervising the work, designing the experiment.

The study was carried out at the University of Valladolid.

J. Olivar $(\bowtie) \cdot$ F. Bravo

Sustainable Forest Management Research Institute Universidad de

Valladolid \& INIA, Avda. de Madrid 44, Palencia 34071, Spain

e-mail: jolivar@pvs.uva.es

\section{S. Bogino}

Departamento de Ciencias Agropecuarias, Facultad de Ingeniería y Ciencias Agropecuarias, Universidad Nacional de San Luis,

Avda. 25 de Mayo 384, Villa Mercedes, San Luis 5730, Argentina

C. Rathgeber $\cdot$ V. Bonnesoeur

Inra, UMR 1092 LERFoB, 54280 Champenoux, France

C. Rathgeber $\cdot$ V. Bonnesoeur

AgroParisTech, UMR 1092, 54000 Nancy, France

\section{J. Olivar $\cdot$ F. Bravo}

Departamento de Producción Vegetal y Recursos Forestales, Universidad de Valladolid, Avda. de Madrid 44, Palencia 34004, Spain of the basal area) for 2 years, based on biweekly band dendrometer recordings. Local relative extractable soil water was derived from the use of a water balance model Biljou(C) (available at https://appgeodb.nancy.inra.fr/biljou/) and used as an explanatory variable.

- Results Radial growth was mainly controlled by soil water availability during the growing season, and differed by crown class. The growth rates of dominant trees were significantly higher than the growth rates of suppressed trees. Removal of $30 \%$ and $45 \%$ of the initial basal area produced a growth release in both dominant and suppressed trees that did not occur under less intense thinning treatments.

- Conclusions Soil water availability was the main driver of radial growth during the growing season. Forest management confirmed its value for ameliorating the effects of water limitations on individual tree growth. These results may help managers understand how altering stand density will differentially affect diameter growth responses of Aleppo pine to short-term climatic fluctuations, promoting forests that are resilient to future climatic conditions.

Keywords Forest management · Stand density ·

Dendrometer $\cdot$ Dominant $\cdot$ Suppressed

\section{Introductions}

In coastal Mediterranean areas, with mild winters and dry summers, cold-season growth dormancy may not occur and, consequently, cambial activity is probably continuous (de Luis et al. 2007). However, in inland areas with continental Mediterranean climate, plants endure double climatic stress, caused by low winter temperatures and summer drought (Mitrakos 1980). As a result, optimal growth conditions are split into two mild periods with higher rainfall (spring and autumn), which suggest a bimodal pattern of cambial activity 
(Camarero et al. 2010). Pine stands are the most extensive coniferous forests in the Mediterranean zone, and Aleppo pine (Pinus halepensis Mill.) is one of the dominant tree species in the Western Mediterranean Basin and the most ecologically important species in semi-arid woodlands (Néeman and Trabaud 2000). Growth rates of $P$. halepensis may be expected to follow the bimodal pattern described above for trees growing in a continential Mediterranean climate, with maximum values in spring and autumn when precipitation is high and temperatures are mild.

In the Mediterranean climate, water is considered to be the most limiting resource for plant growth (Specht 1981). Nevertheless, trees of different sizes and crown classes compete differently for light, water, and other resources within a stand (Peet and Christensen 1987; Orwig and Abrams 1997). Radial growth responses to climate vary considerably according to local tree density and crown class in areas where water is limiting (Linares et al. 2009). Therefore, contrasting growth responses to climate among trees in different crown classes might be particularly relevant for understanding the dynamics of forests dominated by species that are highly sensitive to drought stress (Adams and Kolb 2004).

Climate change models project a decrease in annual mean precipitation and rising air temperatures over the Mediterranean Basin for the twenty-first century, leading to an increase in evapotranspiration (Parry et al. 2007). If water is a limiting resource, as it is predicted to be, one of the most important measures that forest managers have to moderate the influence of climate on tree growth within stands is to thin to residual stand densities that make more water available for the remaining trees (Martín-Benito et al. 2010).

Although forest managers rely heavily on the use of silvicultural treatments that manipulate stand structure and stand dynamics to modify responses to climate change, few studies have directly assessed the effects of stand structure or canopy position on climate-growth relationships (Carnwath et al. 2012). The effect of different silvicultural treatments and stand densities on tree growth response to climate is likely to be a key aspect for influencing forest preservation, particularly in the driest sites (Gea-Izquierdo et al. 2009). The influence of tree density on tree response to climate and drought is not a straightforward issue, since different approaches (e.g., ecophysiological, dendroecological, growth modelling) might give different insights (Misson et al. 2003; Moreno and Cubera 2008).

Short-term data on growth dynamics are required to understand growth responses in relation to climatic variability at short time scales. Dendrometers are a valuable tool for these studies, since they provide short-term measurements of radial fluctuations in relation to climate without disturbing the cambium. Here, we analysed the stem growth dynamics of $P$. halepensis of two different crown classes under four different thinning intensities for 2 years, based on biweekly band dendrometer recordings. We expected that short-term variations in climatic factors and water availability were reflected in the entire growth profile. The following hypotheses were tested: (i) soil water content is the main climatic driver of intra-annual variation in growth of $P$. halepensis at our site, representing semi-arid Mediterranean environments, (ii) suppressed trees are more affected by water stress than dominant trees, and (iii) the reduction of stand density through thinning stimulates diameter growth responses that offset declines expected under more severe water limitation.

\section{Materials and methods}

\subsection{Species and study site}

P. halepensis is one of the most studied Mediterranean trees. Forests dominated by this species provide a valuable system to explore how growth measured at different time scales is constrained by climate (Pasho et al. 2012) and it is considered well-adapted to withstand drought by reducing growth as water availability decreases (Rathgeber et al. 2005; de Luis et al. 2007; Camarero et al. 2010; Pasho et al. 2012). The study site is located in a 60-year-old $P$. halepensis plantation in the north of the Spanish Meseta (Fig. 1). The area is characterized by a continental Mediterranean climate, with low winter temperatures and summer droughts. Mean annual temperature was $11.3{ }^{\circ} \mathrm{C}$ and average annual precipitation was $418 \mathrm{~mm}$ over the last 30 years. The climatic conditions in 2011 and 2012 were among the driest in the late 20th century in Spain. Total annual rainfall was 245 and $244 \mathrm{~mm}$ respectively (40\% lower than the average).

\subsection{Thinning treatments}

Thinning treatments were conducted in autumn 2010 in three stands of similar basal area and stand structure (Table 1). The stand sizes were $40 \mathrm{~m} \times 50 \mathrm{~m}$. Three thinning intensities were considered: $15 \%$ reduction of the basal area (T15), $30 \%$ reduction of the basal area (T30), and $45 \%$ reduction of the basal area (T45), using an unthinned stand as control (T0) (Fig. 2). The reduction of the basal area was based on initial basal area of each stand.

The upper growing stock limit for P. halepensis is determined by the criteria of avoiding density-related mortality, which appears when the stand density index (SDI) is over the $60 \%$ of maximum SDI found for each species (Dean and Baldwin 1993). The lower limit establishes the level at which adequate site occupancy is maintained, and can be set at $35 \%$ of maximum SDI for the species (Long 1985). Keeping the stand between these two limits guarantees adequate density for the stand, avoiding density-related mortality that can provide biomass in case of a forest fire. The thinning treatments 
Fig. 1 a Study area of Pinus halepensis in Spain. b Largescale map of the thinning experiment. c Band dendrometer (Dendrometer Increment Sensor DB20 EMS Brno). d T0 unthinned stand
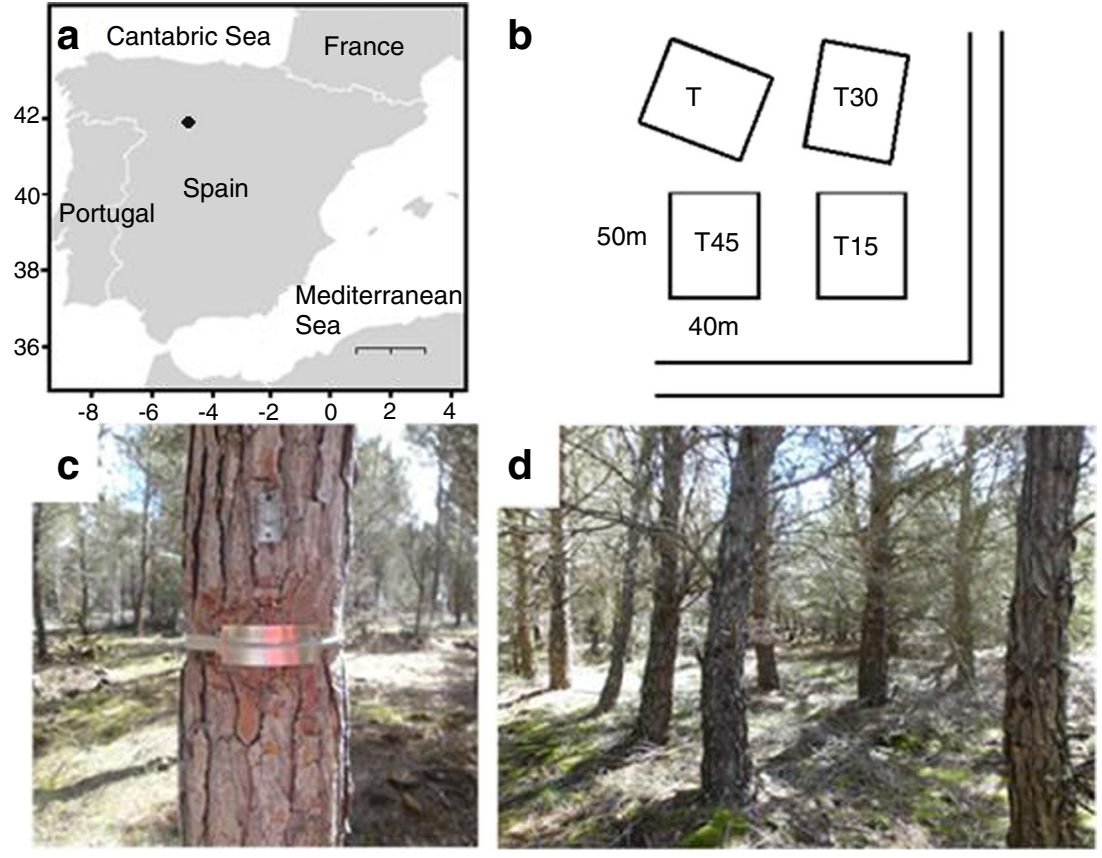

conducted on pine species in this area usually follow a $30 \%$ reduction of the total basal area, and the marginal thinning intensity (MTI), defined as maximum intensity that can be maintained without loss of volume production (Kula 1988), might be close to a $45 \%$ removal of the total basal area.

\subsection{Dendrometer measurements}

To estimate the changes in stem increment, 48 stainless-steel band dendrometers (Dendrometer Increment Sensor DB20 EMS Brno) were mounted around the stem at $1.3 \mathrm{~m}$ height in 12 randomly chosen trees per treatment: six dominant trees (trees with crowns receiving full light from above and partly from the side) and six suppressed (trees with crowns receiving no direct light either from above or from the sides) in each plot. In most cases, the diameter of dominant trees ranged from 20 to $25 \mathrm{~cm}$ and suppressed trees from 10 to $15 \mathrm{~cm}$. However, some suppressed or dominant trees were selected

Table 1 Stand parameters of the four plots. $B A$ Basal area; $D B H$ Diameter at breast height; $\mathrm{H}_{0}=$ Dominant height (mean height of the hundred largest trees per hectare); LAI Leaf area index (projected needle area per unit ground area)

\begin{tabular}{lllllllll}
\hline Stand & $\begin{array}{l}\text { Thinning } \\
\text { intensity }\end{array}$ & $\begin{array}{l}\mathrm{H}_{0} \\
(\mathrm{~m})\end{array}$ & $\begin{array}{l}\text { Initial } \\
\mathrm{BA} \\
\left(\mathrm{m}^{2} / \mathrm{ha}\right)\end{array}$ & $\begin{array}{l}\text { Final } \\
\mathrm{BA} \\
\left(\mathrm{m}^{2} / \mathrm{ha}\right)\end{array}$ & $\begin{array}{l}\text { Initial } \\
\text { mean }\end{array}$ & $\begin{array}{l}\text { FBnal } \\
\text { mean } \\
(\mathrm{cm})\end{array}$ & $\begin{array}{l}\text { Initial } \\
(\mathrm{cm})\end{array}$ & $\begin{array}{l}\text { Final } \\
\text { LAI }\end{array}$ \\
\hline $\mathrm{T} 0$ & $0 \%$ & 10.6 & 22.6 & 22.6 & 18.6 & 18.6 & 1.90 & 1.90 \\
$\mathrm{~T} 15$ & $15 \%$ & 10.1 & 27.6 & 23.5 & 18.2 & 18.9 & 2.19 & 1.90 \\
$\mathrm{~T} 30$ & $30 \%$ & 9.4 & 20.0 & 14.0 & 17.1 & 18.5 & 1.97 & 1.45 \\
$\mathrm{~T} 45$ & $45 \%$ & 9.1 & 20.5 & 11.2 & 17.6 & 21.2 & 1.80 & 1.00 \\
\hline
\end{tabular}

outside of these respective ranges if their relative position in relation to its neighbours gave them the dominant or suppressed status.

Dead outermost tissue of the bark was smoothly and evenly removed with a rasp before attaching the dendrometer. Removing the bark allowed us to reduce swelling and shrinkage from the bark as a component of the increment dynamics. Dendrometer readings to the nearest $0.01 \mathrm{~mm}$ were recorded biweekly over a 2-year period. Readings were done in the morning to reduce diurnal bias because daytime transpiration causes stem shrinkage (Zweifel et al. 2001). Following Keeland and Sharitz (1993), measurements obtained in the first 3 months after installation were discarded for being within the adjustment period of the band dendrometers.

\subsection{Statistical analyses}

Daily climatic data were measured at the closest meteorological station (data provided by Inforriego and the Spanish Meteorological Agency AEMET). Soil water availability to the trees, which can be characterized by relative extractable water (hereafter abbreviated as REW), was included in the analysis. REW is the daily available water standardized by maximum available water. Water stress is assumed to occur when REW drops below a threshold of 0.4 , under which transpiration is gradually reduced due to stomatal closure (Granier et al. 1999). REW was calculated by the daily water balance model Biljou(C (https://appgeodb.nancy.inra.fr/biljou/) (Granier et al. 1999). This model requires daily potential evapotranspiration and rainfall as input climatic data. Potential evapotranspiration (hereafter abbreviated as PET) was calculated 
Fig. 2 Thinning treatments. Grey extracted trees. $T 0$ unthinned stand, $T 1515 \%$ reduction of the total basal area, T30 $30 \%$ reduction of the total basal area, T45 $45 \%$ reduction of the total basal area
TO

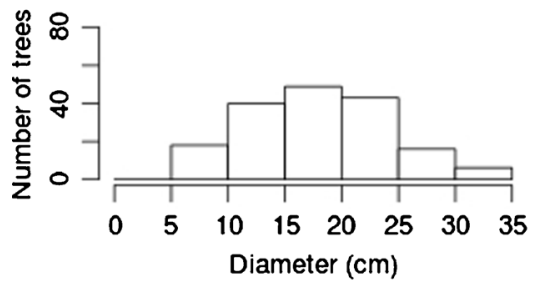

T15

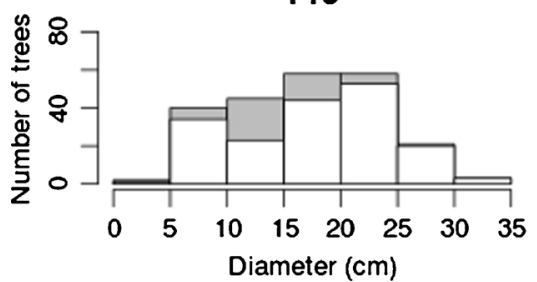

T30

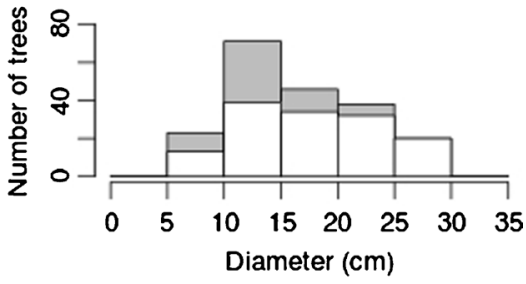

T45

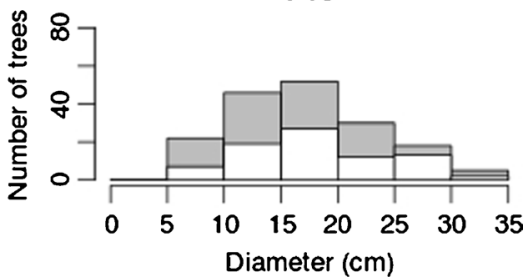

with the Penman potential evapotranspiration equation (Granier et al. 1999). Required site and stand parameters are maximum extractable soil water and leaf area index (LAI). Soil properties were measured at the site and considered homogeneous at the four plots (Table 2). LAI controls stand transpiration, forest floor evapotranspiration, and rainfall interception (Granier et al. 1999). LAI was calculated according to López-Serrano et al. (2000):

$L_{\mathrm{t}}=0.0536 * D^{2.05}$

where $L_{\mathrm{t}}$ is the leaf area of individual tree $\left(\mathrm{m}^{2}\right)$ and $D$ is the $\mathrm{DBH}\left(\mathrm{cm}^{2}\right) ; R^{2}=85.53 \%$ (Table 1$)$. The short time between thinning and the start of diameter growth monitoring allows us to avoid the changes in DBH-crown allometrics expected after thinning. The bioclimatic variables (temperature, precipitation, PET, and REW) were averaged (or accumulated in the case of precipitation) over the 5, 15, and 30 days prior to prior to each diameter measurement, in order to determine which climatic variables were the main constraints for growth and at which temporal scales they act. These weather intervals were selected on the assumption that growth responded to weather or climatic variables that prevailed just prior to each growth period.

Table 2 Soil characteristics of the study area included in the model Biljou@ (https://appgeodb.nancy.inra.fr/biljou/) (Granier et al. 1999)

\begin{tabular}{lll}
\hline Variables & Horizon 1 & Horizon 2 \\
\hline Dept (cm) & $0-30$ & $30-200$ \\
Water reserve (mm) & 36 & 48 \\
Roots (\%) & 75 & 25 \\
Stones (\%) & 1 & 80 \\
Humidity (pF 4.2) & 0.0158 & 0.0158 \\
Apparent density & 1.46 & 1.46 \\
\hline
\end{tabular}

We fitted a linear mixed-effect model using the lme function with R-Package nlme (Laird and Ware 1982). The model was fitted by maximizing the restricted log-likelihood:

$$
\begin{aligned}
& G r_{i j}=\text { intercept }+\alpha_{1} * \operatorname{Clim}_{i j}+\sum \alpha_{2 i k} * T_{k}+\alpha_{3} * S_{i}+\alpha_{4} * \\
& \left(\operatorname{Clim}_{j i} * S_{i}\right)+\sum \alpha_{5 i k} * S_{i} * T_{i}+\mu_{i}+\varepsilon_{i j k} \\
& \mu_{i} \sim N\left(0, \sigma_{\text {Tree }}^{2}\right) \\
& \varepsilon_{i j} \sim N\left(0, \sigma^{2} x\left|\operatorname{Clim}_{i j}\right|^{2 \delta}\right)
\end{aligned}
$$

where $i$ indicates the ith tree, $j$ indicates the $j$ th 2 -week period, $k$ indicates the thinning intensity, $G r$ the radial growth, and Clim the mean (or accumulated) values of the bioclimatic variables (temperature, precipitation, potential evapotranspiration and relative extractable water); $T$ is an indicator variable for the thinning intensities:

if $T_{1}=0, T_{2}=0, T_{3}=0$; then thinning intensity is $0 \%$ if $T_{1}=1, T_{2}=0, T_{3}=0$ then thinning intensity is $15 \%$ if $T_{1}=0, T_{2}=1, T_{3}=0$ then thinning intensity is $30 \%$ if $T_{1}=0, T_{2}=0, T_{3}=1$ then thinning intensity is $45 \%$

$S$ is an indicator variable for the status of the tree $(S=0$ for suppressed trees and $S=1$ for dominant trees), $\mu_{i}$ is a tree random effect, and the variance of the residuals is modeled as $\sigma^{2}$, multiplied by the power of absolute value of the absolute value of covariate Clim. The parameter $\delta$ is estimated by the model (see Zuur et al. 2009).

The period used for growth and climate analysis corresponded only with the main period of stem growth (Deslauriers et al. 2007). Based on our records, the period between 20 November 2011 and 15 April 2012 was excluded from the analysis. Statistical analyses were performed using $\mathrm{R}$ software (R Development Core Team 2011). Initial stand density was similar between sites. However, there were some differences due to microsite effects prevailing in 
Table 3 Comparison of the linear mixed-effect model for the different bioclimatic variables (mean or cumulative value for the previous 5, 15 and 30 days)

\begin{tabular}{llll}
\hline Variable & Delay (days) & AIC & RMSE \\
\hline ETP & 5 & 4,565 & 0.016 \\
& 15 & 4,539 & 0.015 \\
& 30 & 4,463 & 0.014 \\
T & 5 & 4,226 & 0.014 \\
& 15 & 4,155 & 0.013 \\
& 30 & 4,009 & 0.012 \\
PP & 5 & 4,165 & 0.013 \\
& 15 & 4,196 & 0.014 \\
& 30 & 4,165 & 0.013 \\
REW & 5 & 3,745 & 0.011 \\
& 15 & 3,734 & 0.011 \\
& 30 & 3,978 & 0.011 \\
\hline
\end{tabular}

AIC Akaike information criterion; RMSE root mean square error; ETP evapotranspiration; $T$ mean temperature; $P P$ cumulative precipitation; $R E W$ relative extractable water (daily available water standardized by maximum available water)

Mediterranean environments. To test the similarity of past radial growth, increment cores were extracted from 15 trees belonging to the four plots. We fitted a linear model using past growth as a response variable, and a mixed model including the plot random effect. The relative goodness of fit of the models was assessed using the Akaike information criterion (AIC). Since AIC value (4399) did not change when the plot random effect was included, we concluded that there are no significant differences in previous growth between plots.

Climate sensitivity is defined as the degree of growth response to climate variability. Because our growth data are intra-annual, coefficient of variation (hereafter abbreviated as $\mathrm{CV}$ ), which shows the extent of variability in relation to the mean, was calculated in order to assess the climate sensitivity of the radial increment series. CV was calculated for the radial growth during the 2-week growth periods on each tree, and aggregated for trees within status, plots and years.

\section{Results}

The results of the linear mixed-effect model applied for each variable (temperature, precipitation, PET, and REW) confirmed that REW was the main bioclimatic variable that influenced tree radial growth at the studied stands. Mean REW of the previous 15 days showed the lowest AIC values (Table 3). The comparison between mean REW of the previous 15 days and radial increment of the four plots can be observed in Fig. 3. It can be observed how thinning intensity increases REW and radial growth.

We fitted the model with mean REW of the previous 15 days (Table 4) as the climatic variable. Results showed
Fig. 3 Relative extractable water (daily available water standardized by maximum available water) and radial increment of Pinus halepensis at the four plots. T45: black solid line, T30: grey solid line, T15: black dashed line. T0: black dashed line for REW and grey dashed line for radial increment. Water stress is assumed to occur when REW drops below a threshold of 0.4 (Granier et al. 1999). Grey areas show periods not considered for the analysis

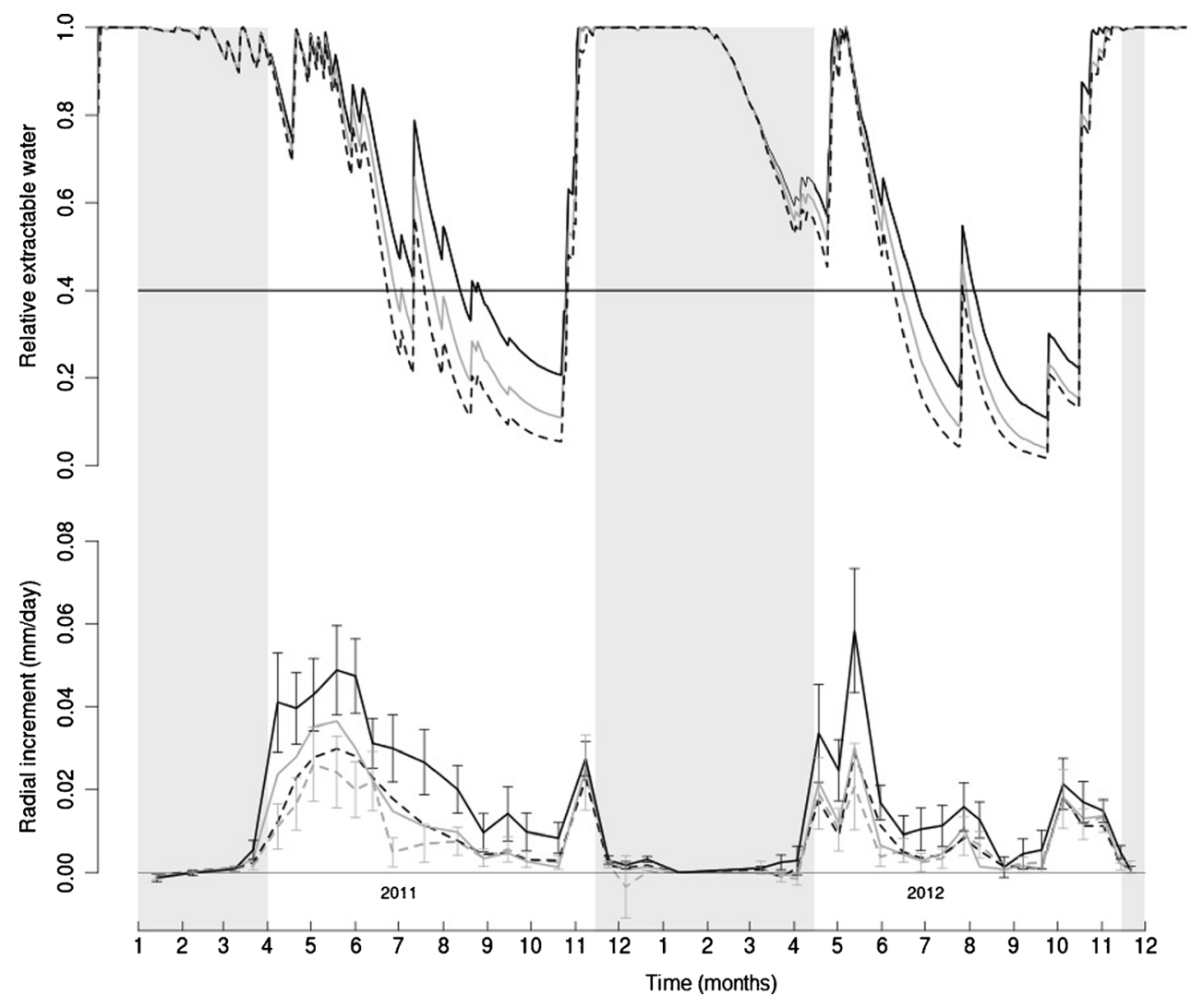


Table 4 Results of the linear mixed-effect model for REW15. Relative extractable water (REW) is the daily available water standardized by maximum available water

\begin{tabular}{llll}
\hline Parameter & Value & Std. error & $P$-value \\
\hline Intercept & -0.0004 & 0.0017 & 0.834 \\
Dominant & 0.0049 & 0.0025 & 0.055 \\
REW & 0.0081 & 0.0018 & $<0.0001$ \\
T15 & -0.0014 & 0.0025 & 0.587 \\
T30 & -0.0006 & 0.0026 & 0.793 \\
T45 & -0.0032 & 0.0026 & 0.223 \\
Dominant * REW & 0.0233 & 0.0018 & $<0.0001$ \\
$\quad$ T15* REW & 0.0055 & 0.0023 & 0.017 \\
T30 * REW & 0.0093 & 0.0024 & $<0.0001$ \\
T45 * REW & 0.0248 & 0.0026 & $<0.0001$ \\
Dominant * T15 & 0.0005 & 0.0036 & 0.896 \\
Dominant * T30 & -0.0042 & 0.0036 & 0.253 \\
Dominant * T45 & -0.0014 & 0.0036 & 0.708 \\
$\sigma^{2}$ Tree & 0.0042 & & \\
\hline
\end{tabular}

TO unthinned stand; T15 15\% reduction of the total basal area; T30 $30 \%$ reduction of the total basal area; $T 4545 \%$ reduction of the total basal area that dominant trees and trees in T30 and T45 had significantly higher growth rates. The comparison between real growth and predicted values of the model for T0 and T45 are shown in Fig. 4. Model predictions are more accurate for dominant than suppressed trees and for T45 than T0.

Growth patterns of the four stands are described in Fig. 5. The growth dynamics of $P$. halepensis showed a bimodal growth pattern, with two major growth phases in spring and autumn and low rates in late summer and beginning of autumn. The spring maximum increment rate was higher than the autumn maximum increment rate, except for T0 in 2011

In order to understand how thinning affects the climategrowth relationship, Fig. 6 represents mean radial growth \pm standard deviation predicted by the model for dominant and suppressed trees with low and high soil water availability ( $\mathrm{REW}=0.2$ and 0.8 respectively). Soil water availability increases growth rates in all thinning intensities, and the T45 treatment produces a higher radial growth increase than the rest of the thinning treatments for the same REW value.
Fig. 4 Real growth (dashed lines) and growth predictions from the model (solid lines). Black dominant trees; grey suppressed trees. T0: unthinned stand. T45: $45 \%$ reduction of the total basal area. Grey areas show periods not considered for the analysis

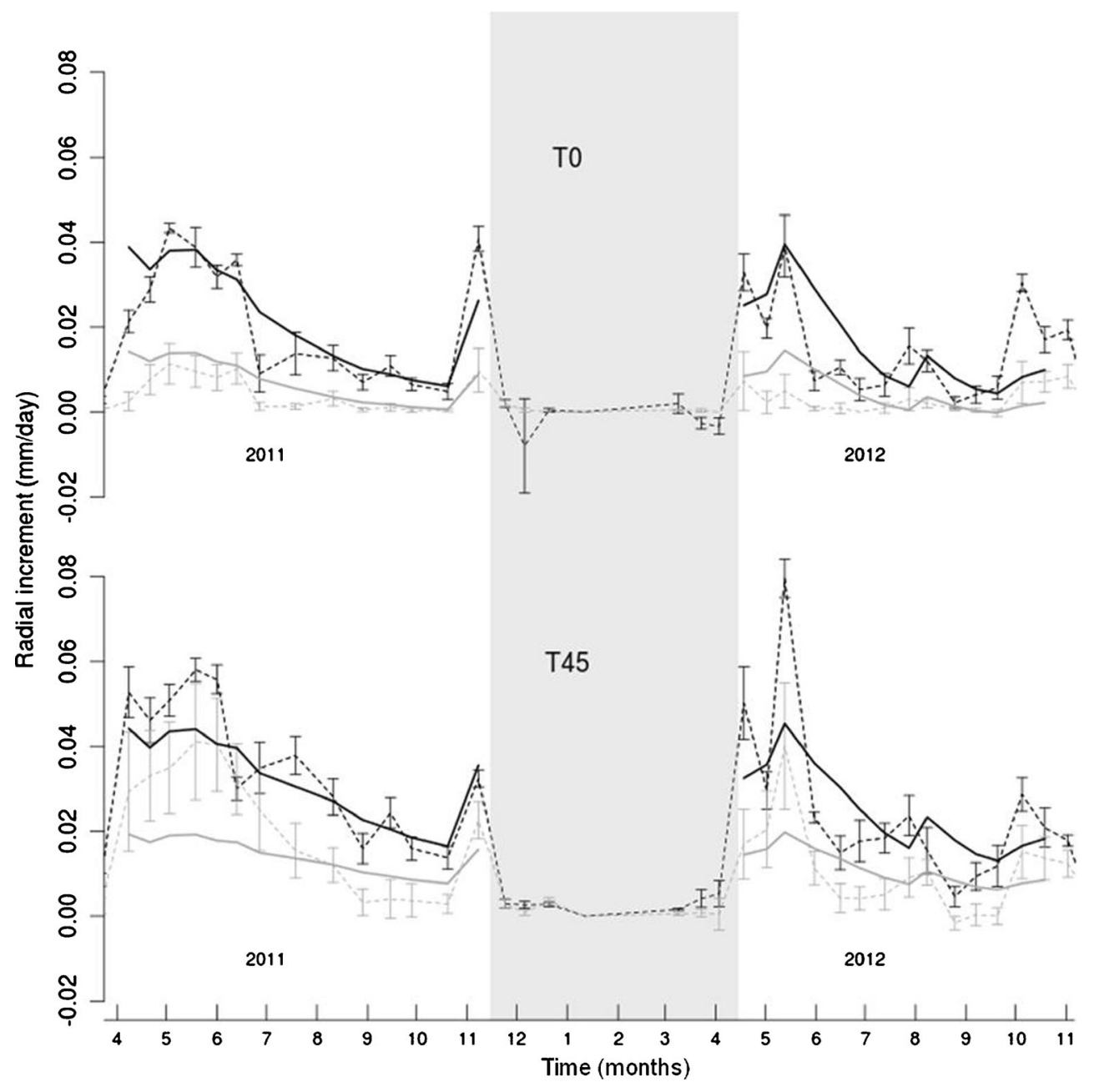




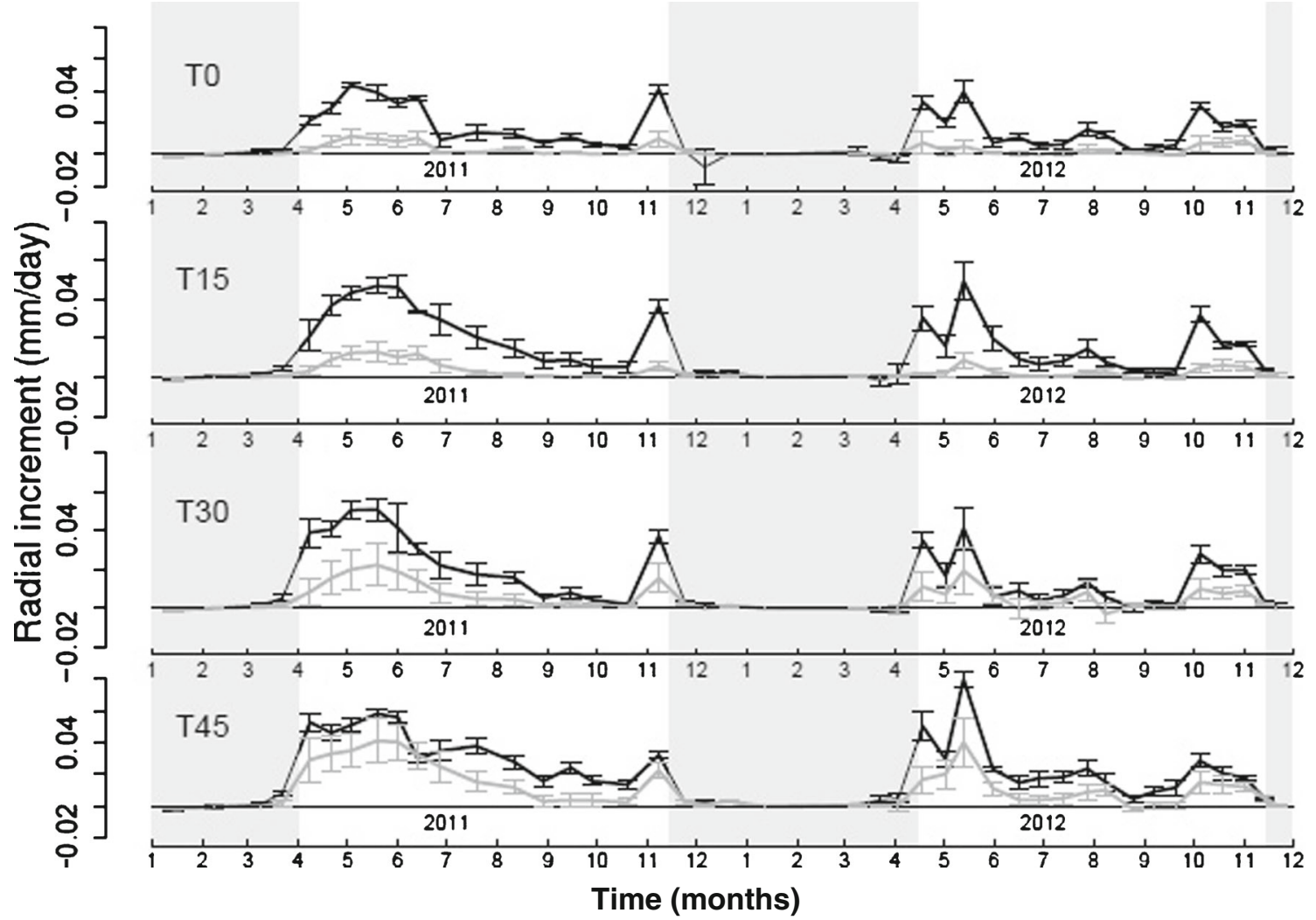

Fig. 5 Growth dynamics of Pinus halepensis at the study site. Black line dominant trees; grey line suppressed trees. Grey areas show periods not considered for the analysis

The analysis of the variance of the growth data (Fig. 7) showed that suppressed trees had higher $\mathrm{CV}$ values than dominant trees. T45 showed the lowest $\mathrm{CV}$ values in both crown classes during the 2 years of study.

Fig. 6 Climate-growth correlations by thinning intensity and canopy class (mean \pm standard deviation). $T 0$ : unthinned stand, T15: $15 \%$ reduction of the total basal area, $T 30: 30 \%$ reduction of the total basal area, and T45: $45 \%$ reduction of the total basal area. Black dominant trees; grey suppressed trees

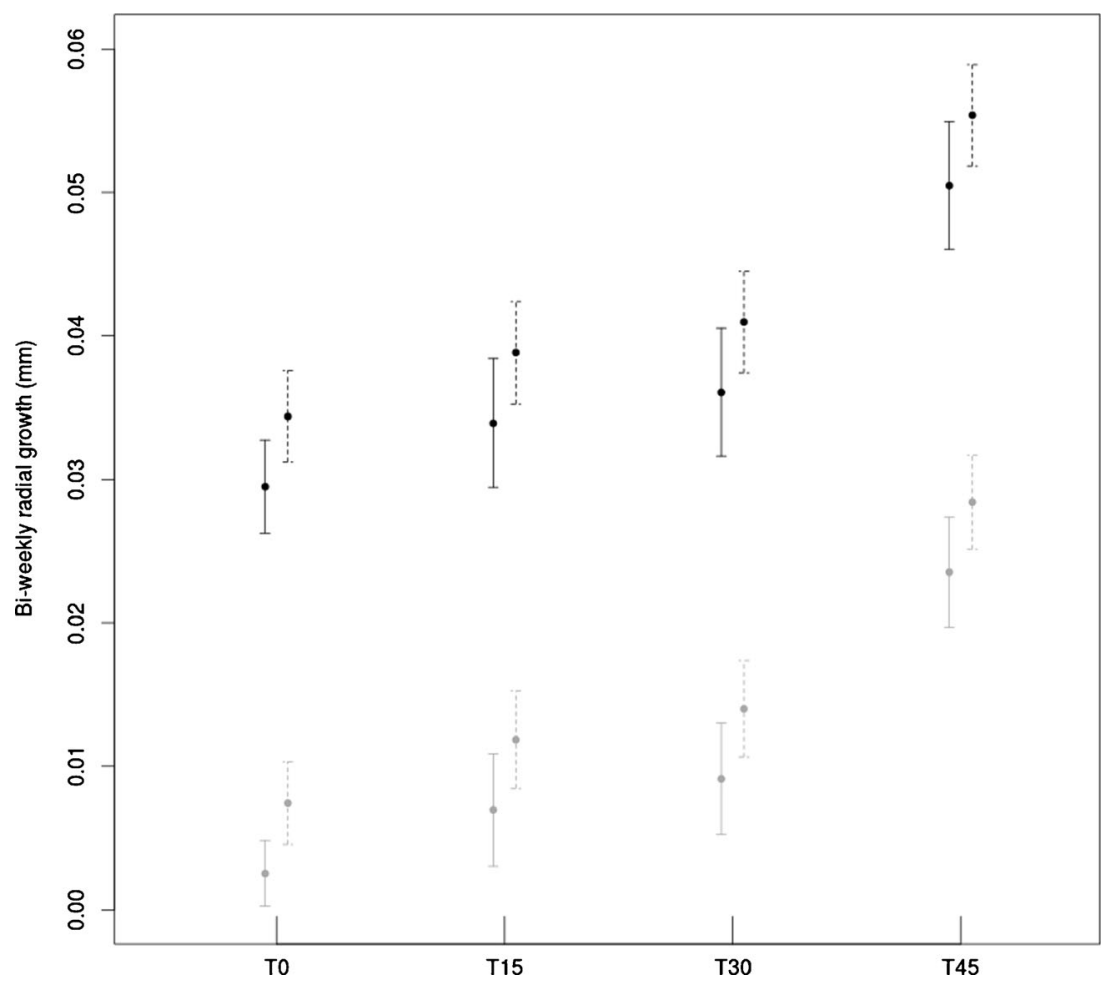



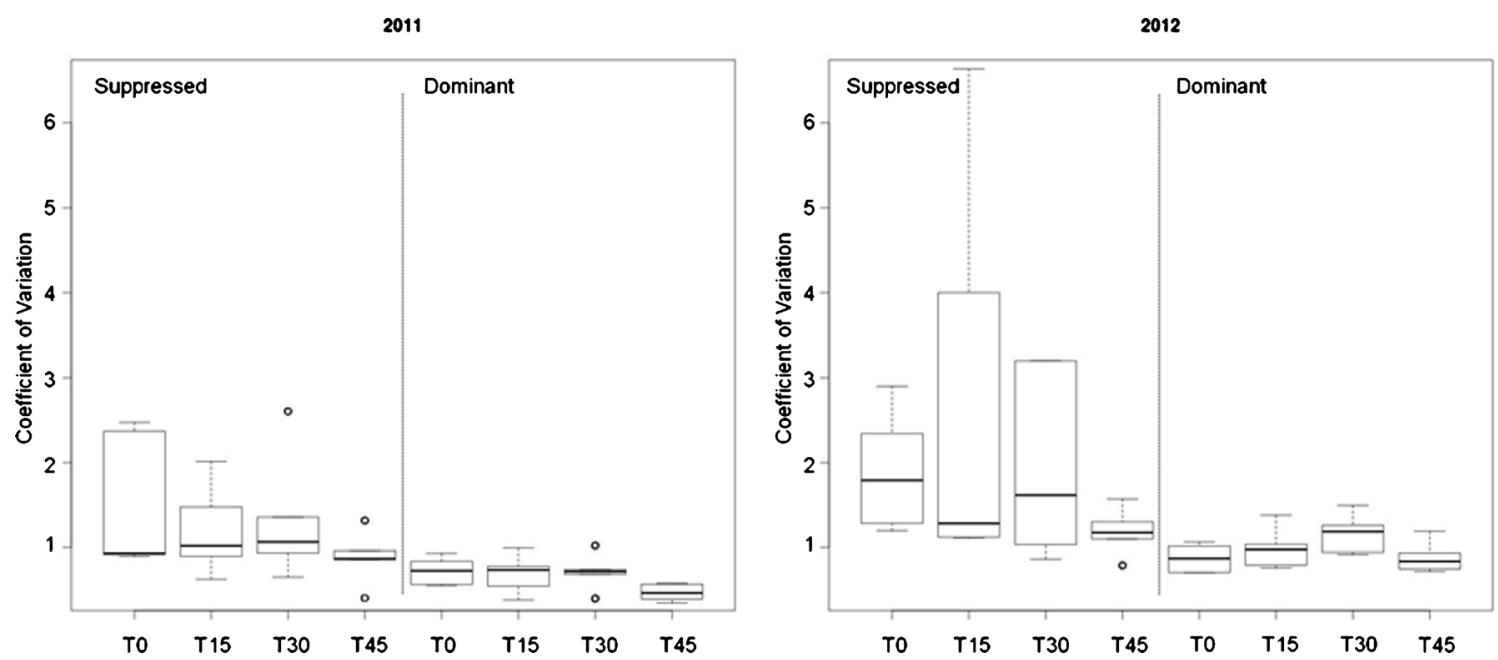

Fig. 7 Coefficient of variation of the growth data of Pinus halepensis at the four plots: unthinned stand (T0), $15 \%$ reduction of the total basal area (T15), $30 \%$ reduction of the total basal area $(T 30)$, and $45 \%$ reduction of the total basal area (T45)

\section{Discussion}

Dendrometers have been criticized when used to record cambial activity with a high temporal resolution, because of the reversible stem shrinking and swelling (de Luis et al. 2007). These criticisms are, to some extent, justified when dendrometers are used to identify cambial growth onset and ending or differentiate growth from stem water content variation in slow-growing species (Deslauriers et al. 2007). However, several studies have been published in recent years describing stem growth phenology and/or assessing growthclimate relationships (Bouriaud et al. 2005; de Luis et al. 2007; Gea-Izquierdo et al. 2009; Linares et al. 2009; Camarero et al. 2010; Gutiérrez et al. 2011). In our study, removing the bark and the fixing interval of the day during which stem radius variation was measured allowed us to improve precision by eliminating effects of bark irregularities and subtle sloughing, and to reduce swelling and shrinkage as a component of the increment dynamics (Zweifel et al. 2001).

REW is the main bioclimatic variable which influences tree radial growth at the studied stands. These results add information to previous inter-annual studies on the same stands (Olivar et al. 2012) that defined monthly rainfall as the main climatic driver of tree growth. The utilisation of soil moisture rather than rainfall is less susceptible to confounding between the effects of water and temperature in the growth response function. Furthermore, soil moisture has more biological meaning than precipitation because it better reflects water availability for trees. These points are particularly relevant for studies performed in Mediterranean regions (Rathgeber et al. 2005).

In the Mediterranean area with a continuous water deficit, at least for $P$. halepensis, wood formation reflects environment conditions for most of the year, and a precipitation event is generally followed by an increase in growth within a week after the event (Attolini et al. 1990). Water availability is expected to be the major limiting factor for growth under a Mediterranean climate, and its influence decreases with altitude in the Mediterranean region, with temperature showing the opposite trend (Cherubini et al. 2003). There is a general idea that radial growth is primarily dependent on the shortterm water availability, which affects the actual tree water status and xylogenesis (Eilmann et al. 2009). In the studied stands, the influence of REW on dominant trees was significantly higher than on suppressed trees. In drought-stressed environments, suppressed trees usually have shallower and less developed root systems than dominant trees, and less moisture is available to them (Van Lear and Kapeluck 1995). Therefore, the amount of available water for suppressed trees is limited to the short-term water reserves concentrated in surface soil layers; while dominant trees, with more developed root systems, can access deeper soil water reserves accumulated over a long period of time (Camarero et al. 2010), inducing higher vulnerability of suppressed trees to water stress.

The growth dynamics of $P$. halepensis had two major growth phases during the growing season, one in spring and another in autumn, interrupted by a period with low or no cambial activity during late summer as a result of drought and high temperatures (Cherubini et al. 2003). This pattern of xylem production is responsible for the frequent formation of intra-annual density fluctuations observed in this species (Olivar et al. 2012). Stem growth started in mid-March in 2001 and April in 2012, when temperatures were high enough for vegetative growth, and stopped growing at the end of November in both years, when temperatures were too low. The radial growth pattern of $P$. halepensis was asymmetrical, with most of the annual growth occurring in spring. The maximum growth rate in spring was the highest of the year except for T0 in 2011, where the autumn maximum growth 
rate was higher. Growth patterns of $P$. halepensis showed high-plasticity in response to climatic conditions during the growing season, which may be an advantage in areas with a Mediterranean climate where the annual rainfall pattern is variable (Gutiérrez et al. 2011). P. halepensis has been characterized as a sensitive Mediterranean species based on the strong response of growth dynamics to changes in climatic conditions (Lev-Yadun 2000). It has also been suggested that the cambium is able to remain active throughout the whole year if climate conditions are favourable (Liphschitz et al. 1984).

Growth rates prior to thinning proved to be not significantly different among the experimental units, suggesting that the thinning intensities were sufficient to cause differences in diameter growth rates. Specifically, we can conclude that $\mathrm{T} 30$ and T45 thinning treatments were able to induce a growth release on both crown classes that did not occur under less intense thinning treatments. Thinning is less effective on dry sites if it is not intense enough, because inter-tree competition for water is stronger and drier sites cannot support stands of sufficiently high density to warrant thinning (Cotillas et al. 2009; Linares et al. 2009; Moreno and Cubera 2008). Thus, a high residual stand density that is not sufficiently reduced by thinning, coupled with the more limiting climatic conditions, should have obscured the advantages of thinning on less intense thinning treatments (Misson et al. 2003).

Growth variability was higher in suppressed than in dominant trees. T45 showed the lowest CV values in both crown classes, which means higher homogeneity of the growth data. Tree growth responses to climate are highly contextdependent (Carnwath et al. 2012). However, these results are in agreement with the idea that in semi-arid environments, suppressed trees usually have more limited access to soil water reserves than dominant trees, due to their shallower and less developed root systems, especially in high density stands. Therefore, their growth rates fluctuate depending on shortterm water reserves concentrated in surface soil layers, while dominant trees with more developed root systems and suppressed trees in thinned stands and therefore better access to water show more homogeneous growth rates.

The reduction of stand density through thinning has been suggested to improve the resistance of individual trees to drought stress and the extent of this differential response changes within the same species along climatic gradients (Misson et al. 2003; Moreno and Cubera 2008; GeaIzquierdo et al. 2009). However, open stands should not be concluded to be universally desirable (Gea-Izquierdo et al. 2009). Forest managers should retain adequate stand density to mitigate the effect of climatic extremes, taking other ecosystem parameters such as regeneration or soil protection into account. Less dense and more diverse stands could be promoted by mixing species with different drought resistance to avoid or limit further growth declines in plantations.
Acknowledgments The authors wish to thank Cristina Prieto, Irene Ruano and Lucía Risio for their help on the installation of the dendrometers, Inforriego and the Spanish Meteorological Agency for providing the meteorological data, Cristóbal Ordoñez for his help on the field data collection, and Jorge Leporati for his help with data analysis.

Funding Funding was provided by the Spanish Research National Projects AGL-2007-65795-C02-01 and AGL2011-29701-C02-02.

\section{References}

Adams HD, Kolb TE (2004) Drought responses of conifers in ecotone forests of northern Arizona: tree ring growth and leaf d13C. Oecologia 140:217-225

Attolini MR, Calvani F, Galli M, Nanni T, Ruggiero L, Schaer E, Zuanni F (1990) The relationship between climatic variables and wood structure in Pinus halepensis Mill. Theor Appl Climatol 41:121127

Bouriaud O, Leban J-M, Bert D, Deleuze C (2005) Intraannual variations in climate influence growth and wood density of Norway spruce. Tree Physiol 25:651-660

Carnwath GC, Peterson DW, Nelson CR (2012) Effect of crown class and habitat type on climate-growth relationships of ponderosa pine and Douglas-fir. For Ecol Manage 285:44-52

Camarero JJ, Olano JM, Parras A (2010) Plastic bimodal xylogenesis in conifers from continental Mediterranean climates. New Phytol 185: $471-480$

Cherubini P, Gartner BL, Tognetti R, Bräker OU, Schoch W, Innes JL (2003) Identification, measurement and interpretation of tree rings in woody species from Mediterranean climates. Biol Rev Camb Philos Soc 78:119-148

Cotillas M, Sabaté S, Gràcia C, Espelta JM (2009) Growth response of mixed Mediterranean oak coppices to rainfall reduction: Could selective thinning have any influence on it? For Ecol Manage 258: $1677-1683$

Dean TJ, Baldwin VCJR (1993) Using a density-management diagram to develop thinning schedules for loblolly pine plantations. Research Paper SO-275. USDA, Forest Service, Southern Forest Experiment Station.

De Luis M, Gričar J, Čufar K, Raventós J (2007) Seasonal dynamics of wood formation in Pinus halepensis from dry and semi-arid ecosystems in Spain. IAWA J 28:389-404

Deslauriers A, Rossi S, Anfodillo T (2007) Dendrometer and intra-annual tree growth: What kind of information can be inferred? Dendrochronologia 25:113-124

Eilmann B, Zweifel R, Buchmann N, Fonti P, Rigling A (2009) Droughtinduced adaptation of the xylem in Scots pine and pubescent oak. Tree Physiol 29:1011-1020

Gea-Izquierdo G, Martín-Benito D, Cherubini P, Cañellas I (2009) Climate-growth variability in Quercus ilex L. west Iberian open woodlands of different stand density. Ann For Sci 66:802

Granier A, Bréda N, Biron P, Viville S (1999) A lumped water balance model to evaluate duration and intensity of drought constraints in forest stands. Ecol Model 116:269-283

Gutiérrez E, Campelo F, Camarero JJ, Ribas M, Muntán E, Nabais C, Freitas H (2011) Climate controls act at different scales on the seasonal pattern of Quercus ilex L. stem radial increments in NE Spain. Trees 25:4637-4647. doi:10.1007/s00468-011-0540-3

Keeland BD, Sharitz RR (1993) Accuracy of tree growth measurements using dendrometer bands. Can J Forest Res 23:2454-2457

Kula E (1988) The economics of forestry: modern theory and practice. Timber Press, Portland, USA

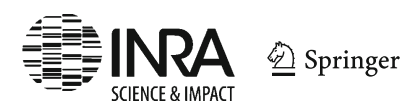


Laird NM, Ware JH (1982) Random effects models for longitudinal data. Biometrics 38:963-974

Lev-Yadun S (2000) Wood structure and the ecology of annual growth ring formation in Pinus halepensis and P. brutia. Ecology, biogeography and management of Pinus halepensis and P. brutia. In: Néeman, G, Trabaud L (eds) Forest ecosystems in the Mediterranean Basin. Backhuys, Leiden, pp 67-78

Linares JC, Camarero JJ, Carreira JA (2009) Plastic responses of Abies pinsapo xylogenesis to drought and competition. Tree Physiol 29: $1525-1536$

Liphschitz N, Lev-Yadun S, Rosen E, Waisel Y (1984) The annual rhythm of activity of the lateral meristems (cambium and phellogen) in Pinus halepensis Mill. and Pinus pinea L. IAWA Bull n.s. 5:263274

Long JN (1985) A practical approach to density management. For Chron 61:23-27

López-Serrano FR, Landete-Castillejos T, Martínez-Millán J, del CerroBarja A (2000) LAI estimation of natural pine forest using a nonstandard sampling technique. Agr Forest Meteorol 101:95-111

Martín-Benito D, del Río M, Heinrich H, Helle G, Cañellas I (2010) Response of climate-growth relationships and water use efficiency to thinning in a Pinus nigra afforestation. For Ecol Manage 259: 967-975

Misson L, Nicault A, Guiot J (2003) Effects of different thinning intensities on drought response in Norway spruce (Picea abies (L.) Karst.). For Ecol Manage 183:47-60

Mitrakos KA (1980) A theory for Mediterranean plant life. Acta Oecol 1: 245-252

Moreno G, Cubera E (2008) Impact of stand density on water status and leaf gas exchange in Quercus ilex. For Ecol Manage 254:74-84

Néeman G, Trabaud L (2000) Ecology, biogeography and management of Pinus halepensis and Pinus brutia forest ecosystems in the Mediterranean Basin. Backhuys, Leiden

Olivar J, Bogino S, Spiecker H, Bravo F (2012) Climate impact on growth dynamic and intra-annual density fluctuations in Aleppo pine (Pinus halepensis) trees of different crown classes. Dendrochronologia 30:35-47

Orwig DA, Abrams MD (1997) Variation in radial growth responses to drought among species, site, and canopy strata. Trees 11:474-484

Parry ML, Canziani OG, Palutikof JP, van der Linden PJ, Hanson CE (2007) Climate Change 2007: impacts, adaptation and vulnerability. Contribution of Working Group II to the Fourth Assessment Report of the Intergovernmental Panel on Climate Change. Cambridge University Press, Cambridge

Pasho E, Camarero JJ, Vicente-Serrano SM (2012) Climatic impacts and drought control of radial growth and seasonal wood formation in Pinus halepensis. Trees 26:1875-1886. doi:10.1007/s00468-0120756-x

Peet RK, Christensen NL (1987) Competition and tree death. Bioscience 37:586-594

R Development Core Team (2011) R: A language and environment for statistical computing. R Foundation for Statistical Computing, Vienna, Austria. ISBN 3-900051-07-0, URL. http://www.Rproject.org.

Rathgeber C, Misson L, Nicault A, Guiot J (2005) Bioclimatic model of tree radial growth: application to French Mediterranean Aleppo pine forests. Trees 19:162-176

Specht RL (1981) Primary production in Mediterranean climate ecosystems regenerating after fire. In: Di Castri F, Goodall DW, Specht RL (eds) Mediterranean-type shrublands. Elsevier, Amsterdam

Van Lear DH, Kapeluck PR (1995) Above- and below-stump biomass and nutrient content of a mature loblolly pine plantation. Can J For Res 25:361-367

Zuur A, Ieno EN, Walker N, Saveliev AA, Smith GM (2009) Mixed effects models and extensions in ecology with R. Springer, New York

Zweifel R, Item H, Häsler R (2001) Link between diurnal stem radius changes and tree water relations. Tree Physiol 21:869-877 